\title{
Microbial and enzymatic control of pitch in the pulp and paper industry
}

\author{
Ana Gutiérrez • José C. del Río • Angel T. Martínez
}

Received: 22 December 2008 /Revised: 1 February 2009 / Accepted: 1 February 2009 / Published online: 26 February 2009

(C) Springer-Verlag 2009

\begin{abstract}
Pitch control is an important aspect in pulp and paper manufacture, and the first example where microbial biotechnology provided successful solutions in this industrial sector. Triglycerides cause deposits in softwood mechanical pulping, and both microbial and enzymatic products have been commercialized to be applied on wood and pulp, respectively. The former are based on colorless strains of sapstain fungi. The latter are improved lipases, including thermostable variants from directed evolution. These enzymes are among the additives of choice in pulping of high-resin-content softwoods. However, lipases are not useful when pitch originates from other lipids, such as steroids and terpenes, and the sapstain inocula are also only partially effective. In the search for stronger biocatalysts to degrade recalcitrant lipids, the potential of white-rot fungi and their enzymes has been demonstrated. When inocula of these fungi are used, wood treatment must be controlled to avoid cellulose degradation. However, the efficiency and selectivity of the laccase-mediator system permits its integration as an additional bleaching stage. A double benefit can be obtained from these treatments since pitch is controlled at the same time that residual lignin is removed facilitating the implementation of totally chlorine free pulp bleaching.
\end{abstract}

\footnotetext{
A. Gutiérrez $(\bowtie) \cdot J$. C. del Río

Instituto de Recursos Naturales y Agrobiología, CSIC, PO Box 1052, E-41080 Seville, Spain

e-mail: anagu@irnase.csic.es

A. T. Martínez

Centro de Investigaciones Biológicas, CSIC,

Ramiro de Maeztu 9,

E-28040 Madrid, Spain
}

Keywords Pitch deposits · Paper pulps · Wood fungi . Fungal enzymes $\cdot$ Laccase-mediator system

\section{Pitch problems in pulp and paper manufacture}

Lipophilic extractives (Fig. 1), i.e., the non-polar extractable fraction from wood and other lignocellulosic materials often referred to as wood resin, includes alkanes (1), fatty alcohols (2), fatty acids (3), resin acids (4), sterols (5), other terpenoids $(\mathbf{6})$, conjugated sterols $(\mathbf{7 , 8})$, triglycerides $(\mathbf{9})$ and waxes (10). These lipophilic compounds cause the so-called pitch deposits along the pulp and paper manufacturing processes. Pitch deposition is a serious problem in the pulp and paper industry since it is responsible for reduced production levels, higher equipment maintenance costs, higher operating costs, and an increased incidence of defects in the finished products, which reduces quality and benefits (Back and Allen 2000). Furthermore, process effluents containing wood extractives may be toxic and harmful to the environment (Leach and Thakore 1976; Liss et al. 1997).

There are significant differences in resin content and composition between the different angiosperm and gymnosperm species, and even between different parts of the plant (Back 2000). Some differences are also due to the growing conditions, age of the tree, and other genetic and environmental factors. The resin components of softwoods (woody gymnosperms) commonly used in the pulp and paper industry, such as Scots pine (Pinus sylvestris) and Norway spruce (Picea abies), have been extensively studied (Ekman and Holmbom 2000). Triglycerides, resin acids, and fatty acids represent a high percentage of Scots pine extractives, their composition also varying between sapwood and heartwood of the same species, the latter mainly consisting of resin acids (Fig. 2a and d). Norway spruce contains 
Fig. 1 Chemical structures of compounds representing the main classes of lipophilic extractives found in woody and non-woody plants: 1, octadecane; 2, 1-hexadecanol; $\mathbf{3}$, palmitic acid; 4, abietic acid; $\mathbf{5}$, sitosterol; 6, betulinol; 7, sitosteryl linoleate; $\mathbf{8}$, sitosteryl $3 \beta$-D-glucopyranoside; $\mathbf{9}$, trilinolein; and 10, octacosyl hexadecanoate

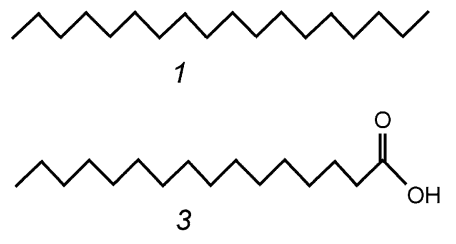<smiles>CCCCCCCCCCCCCCCCO</smiles><smiles>[3H]C1CC=C2CC(OC(=O)CCCCCCC=CCC=CCCCCC)CCC2(C)C2CCC3(C)C(CCC3C(C)CCC(CC)C(C)C)CCC12C</smiles>

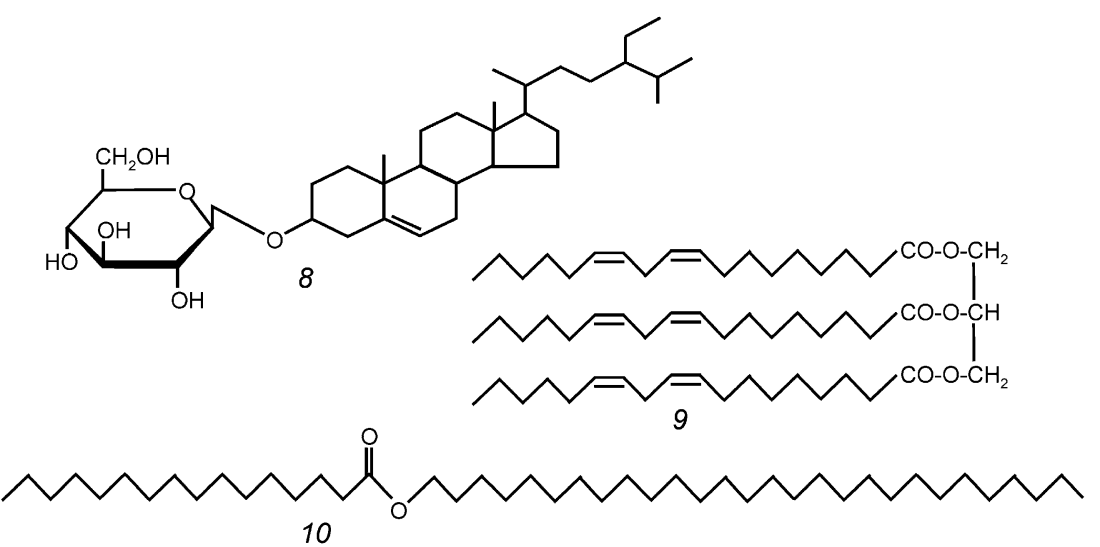

similarly high amounts of triglycerides, resin acids, and steroids. The above lipophilic compounds are often associated to pitch problems (Back and Allen 2000; Ekman and Holmbom 2000).

Among hardwoods, silver birch (Betula pendula) and trembling aspen (Populus tremuloides) have been traditionally used as raw materials for paper pulp production, and therefore, their wood resins have been thoroughly studied (Ekman and Holmbom 2000). A significantly higher proportion of sterols and other unsaponifiable lipids has been reported in birch and aspen compared to softwoods, although triglycerides predominate in both species. Sterol esters and waxes on one side (Chen et al. 1995) and triterpenols and saturated fatty acids on the other side (Bergelin et al. 2005) have been reported to be the main compounds present in pitch deposits in aspen and birch processing, respectively. A huge amount of information on the composition of lipophilic extractives from another hardwood, eucalypt (Eucalyptus globulus and other species) wood (Fig. 3a), has emerged during last 10 years due to the increasing consumption of this fast-growing hardwood by the paper pulp industry. Free and conjugated sterols (as fatty acid esters and glycosides) are the main lipophilic components of eucalypt wood together with other steroids and free fatty acids (Freire et al. 2002; Gutiérrez and del Río 2001; Gutiérrez et al. 1999a, 2001a; Rencoret et al. 2007), being also the main responsible for pitch deposition in pulp and paper manufacture (del Río et al. 1998, 1999, 2000; Freire et al. 2005; González-Vila et al. 1997; Gutiérrez et al. 2001b, c; Silvestre et al. 1999).

On the other hand, the chemical composition of lipophilic extractives from non-woody species used by the pulp and paper industry, has not been studied to the same extent as that of woody species, although during the last years more knowledge has been produced (del Río and Gutiérrez 2006; Gutiérrez and del Río 2003a, b, Gutiérrez et al. 2004, 2006d, 2008; Morrison and Akin 2001). Alkanes, fatty alcohols and aldehydes, sterols and waxes are the major compounds identified in non-woody plants such as flax, hemp, kenaf, sisal and abaca, which are used in the production of high-quality pulps for specialty papers. In pulping of non-woody plants, such as hemp, fatty 


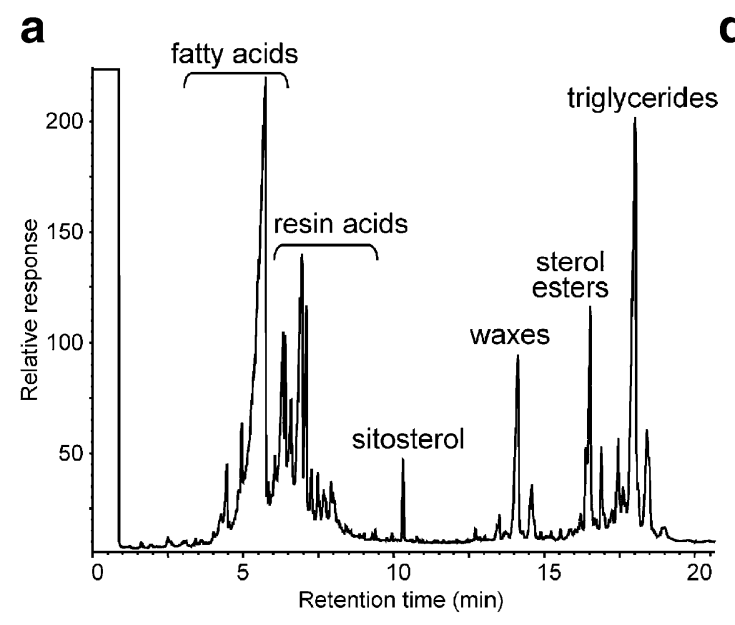

d
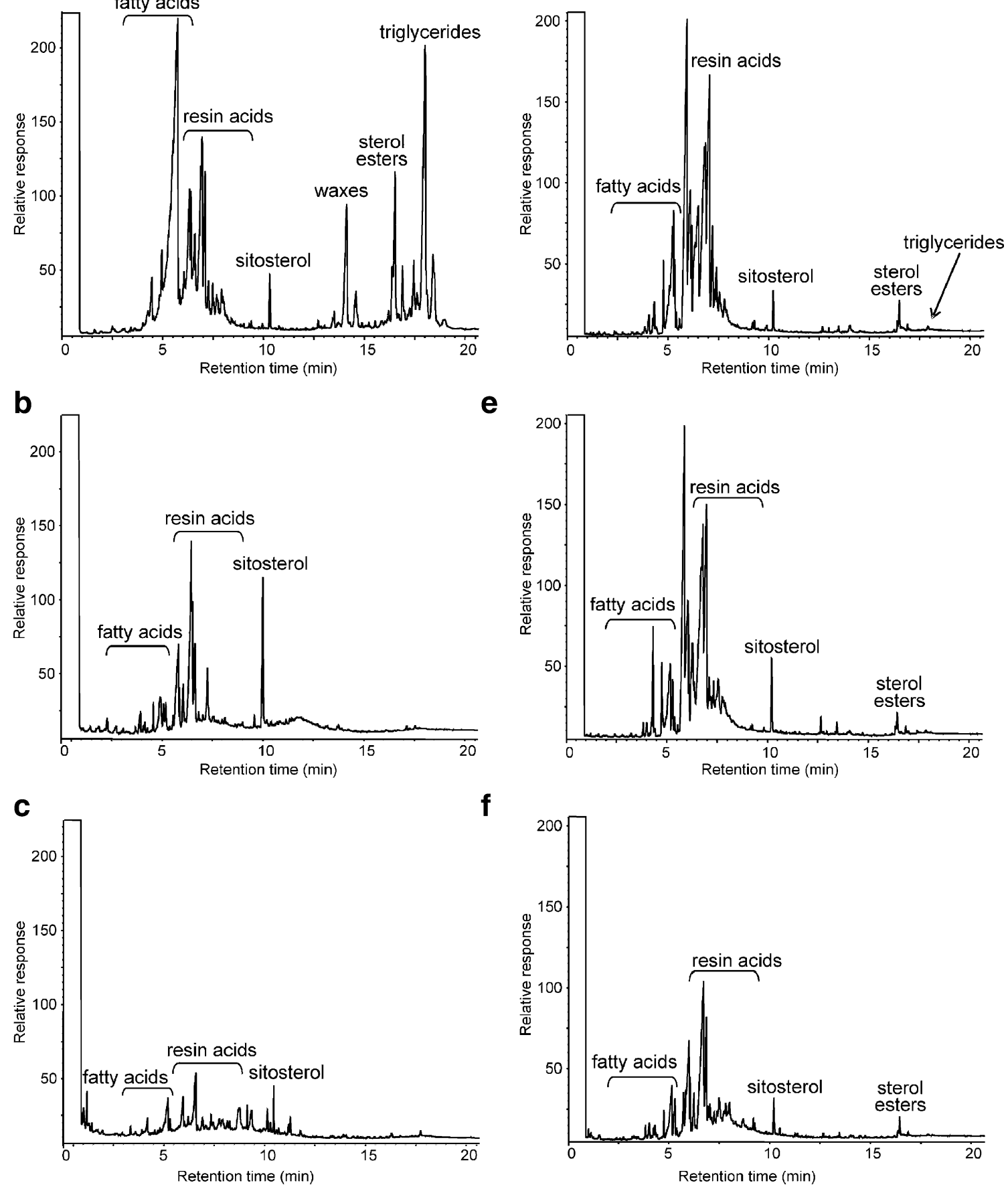

Fig. 2 Gas-chromatography analysis of the lipophilic extractives from Scots pine (P. sylvestris) sapwood and heartwood after treatment with a sapstain fungus and a white-rot fungus: a pine sapwoood control; b pine sapwood treated with Ophiostoma ainoae; c pine sapwood

treated with Bjerkandera sp.; d pine heartwood control; e pine heartwood treated with $O$. ainoae; and $\mathbf{f}$ pine heartwood treated with Bjerkandera sp. Adapted from Martínez-Íñigo et al. (1999)

alcohols, alkanes, and sterols are among the compounds responsible for pitch deposits (Gutiérrez and del Río 2005).

The lipophilic extractives present in the raw materials may cause pitch problems along the entire pulp and paper manufacturing processes (pulping, bleaching, and paper machine). The nature and severity of pitch problems

depend not only on the raw materials used, but also on the industrial processes of pulping and bleaching applied at the mill. In this way, mechanical pulping only affects slightly the composition of extractives. By contrast, chemical pulping saponifies triglycerides (Fengel and Wegener 1984), whereas sterol and triterpenol esters are much less affected 

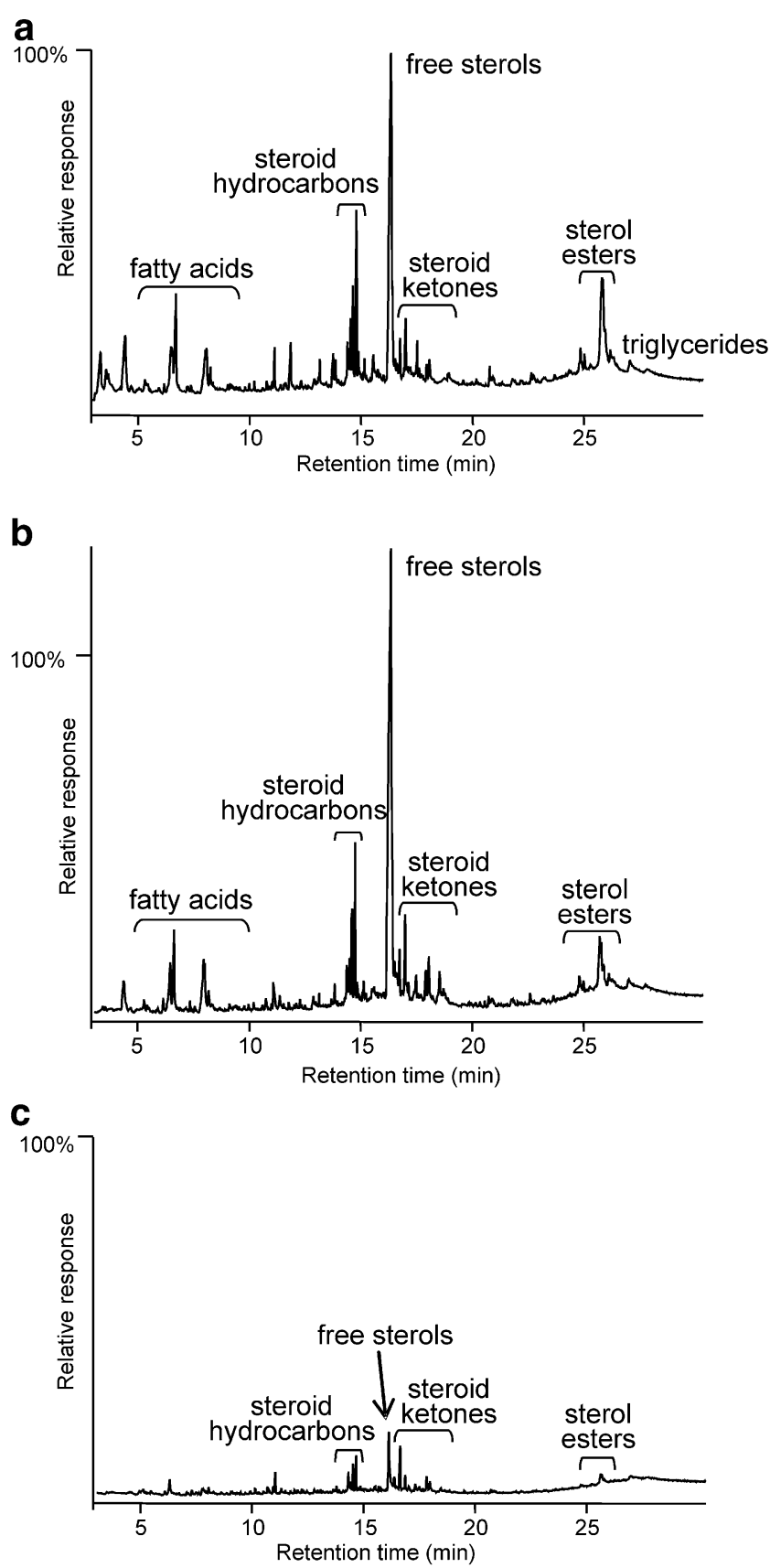

Fig. 3 Gas-chromatography analysis of the lipophilic extracts from eucalypt (E. globulus) wood after treatment with a sapstain fungus and a white-rot fungus: a control; b eucalypt wood treated with Cartapip ${ }^{\mathrm{TM}}$ 97 (O. piliferum); and c eucalypt wood treated with $P$. radiata. Adapted from Gutiérrez et al. (1999b)

(Bergelin and Holmbom 2003; Gutiérrez et al. 2001c). The wood extractives remaining in the unbleached pulp are carried over to the bleach plant, where they react with the bleaching agents (Jansson et al. 1995). The use of totally chlorine free (TCF) bleaching in place of elementary chlorine free $(\mathrm{ECF})$ bleaching is increasing the severity of pitch problems due to lower reactivity with pulp lipids (Bergelin et al. 2003; Freire et al. 2005, 2006; Gutiérrez et al. 2001c).
Pitch colloidal particles surviving bleaching can deposit in pulp reducing its quality, or on equipment causing the shutdown of mill operations. Finally, the lipophilic extractives present in pulps are at the origin of pitch problems in the paper mill (Allen 2000a). Pitch problems are increased in mills with a high degree of water circuit closure (Otero et al. 2000).

Traditional methods to control pitch problems include deliberate storage of logs or wood chips in the mill before pulping (natural "seasoning") and adsorption or dispersion of the pitch particles with chemicals in the pulping and papermaking processes, which can be accomplished by adding alum, talc, ionic or nonionic dispersants, cationic polymers and other types of additives (Allen 2000a, b). During wood storage, the content of extractives is decreased since some of them are subjected to hydrolytic or oxidative transformation by plant enzymes as well as by the action of wood colonizing microorganisms. The reactions of wood resin components during storage have been studied for several pulpwood species including spruce, pine, birch, aspen and eucalypt (Ekman 2000; Gutiérrez et al. 1998; Silvério et al. 2008). However, prolonged storage cause decreases in pulp brightness and yield due to the uncontrolled action of microorganisms, therefore, the industrial practice today does not include overlong log or chip storage times. As an alternative, the use of selected fungi to accelerate and control the seasoning of wood, or enzymes to treat the pulp has been considered as described below.

\section{Fungal pitch control}

Fungal removal of extractives from wood prior to pulping has been suggested as a promising technology to control pitch problems. The ability to colonize lignified plant materials is a characteristic of wood decaying fungi, including white-rot, brown-rot, soft-rot, and sapstain species. The fungi causing the two former wood rots are basidiomycetes characterized by their ability to efficiently degrade lignin and cellulose, respectively. The soft-rot fungi are mostly ascomycetous fungi (i.e., ascomycetes and their conidial states) producing cavities in the secondary cell wall after a limited degradation of carbohydrates. Finally, a limited number of ascomycetous fungi, called staining fungi, colonize wood through parenchymatic rays and resin canals causing discoloration of sapwood tissues, due to the presence of melanin-like pigments in the fungal hyphae (Zimmerman et al. 1995), but a limited degradation that mainly affects extractives and water-soluble materials (Martínez et al. 2005). Since most lipophilic compounds involved in the formation of pitch deposits are concentrated in wood rays and resin canals, the sapstain fungi were the first 
candidates for the biological control of pitch. Woodrotting basidiomycetes have also been investigated for application in paper pulp manufacturing. Brown-rotters are of low applied interest since they degrade cellulose, although they could be of use in bioethanol production for partial depolymerization of crystalline cellulose. However, some white-rot fungi can remove lipophilic extractives (and lignin) with a limited attack to the cellulose polymer, as explained below. In addition, wood treatment with bacteria to remove lipophilic extractives has also been suggested (Burnes et al. 2000; Kallioinen et al. 2003).

\section{Sapstain fungi}

Treatment of wood chips with sapstain fungi that degrade resinous compounds prior to pulping has been proposed as an alternative method for pitch control (Brush et al. 1994; Farrell et al. 1993). Sapstain, also called blue stain, is caused by pioneer colonizing fungi, such as Ophiostoma (Fig. 4a), Ceratocystis, Leptographium, or Sphaeropsis species that utilize fatty acids, triglycerides simple carbohydrates, and other components of the sapwood (Farrell et al. 1993). Additionally, these fungi can rapidly colonize non-sterile wood chips. Research on the biotechnological application of sapstain fungi for wood depitching has been mainly focused on Ophiostoma piliferum strains. These research efforts led to the commercialization of an albino

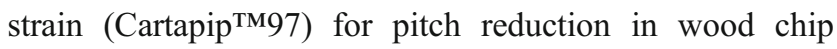
piles. This and other colorless strains were obtained by classical mating (followed by single ascospore isolation) and neither mutagenesis nor genetic engineering methods were applied. $O$. piliferum is an ascomycete found throughout the world in the forest and in chip piles and is commonly referred to as one of the sapstain fungi, but the albino fungal product has no staining effect.

Cartapip ${ }^{\text {TM97 }}$ was originally marketed by Sandoz Chemicals/Clariant Corporation, and has been used by the pulp and paper industry for the past 15 years. A $90 \%$ decrease of triglycerides causing pitch problems in the manufacture of mechanical pulp and acidic sulfite pulp was reported after Cartapip ${ }^{\mathrm{TM}}$ treatment of pine wood (Farrell et al. 1993). The effectiveness of this strain and other Ophiostoma species to degrade triglycerides and free fatty acids has been demonstrated by several studies on both softwood (Brush et al. 1994; Dorado et al. 2000a; MartínezÍñigo et al. 1999) and hardwood species (Gutiérrez et al. 1999b; Rocheleau et al. 1999). However, some studies report a low efficiency in sterol esters removal (Chen et al. 1994; Josefsson et al. 2006; Leone and Breuil 1998) whereas other authors report that a significant removal of sterol esters can be obtained (Gutiérrez et al. 1999b; Martínez-Íñigo et al. 1999). On the other hand, Cartapip ${ }^{\mathrm{TM}}$ and other sapstain
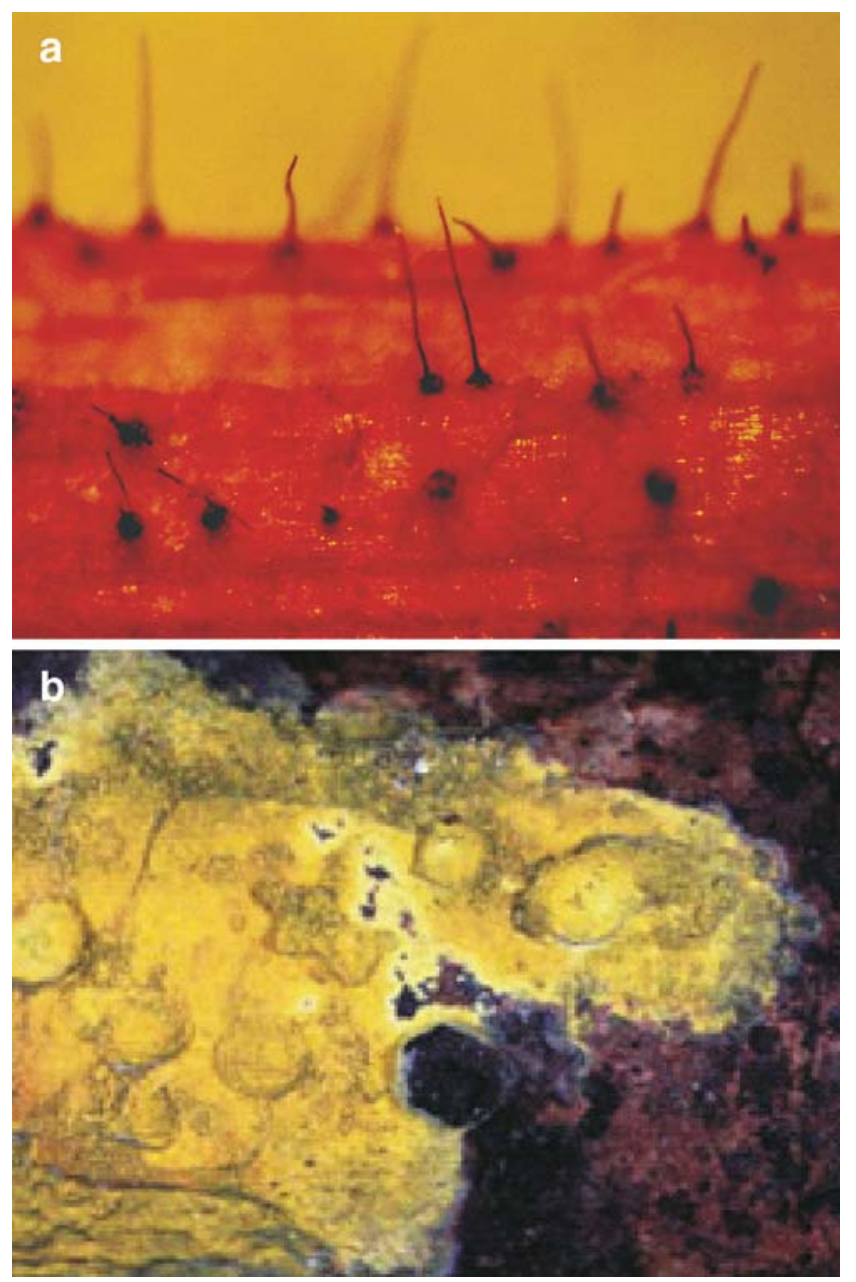

Fig. 4 Wood-rotting fungi: a sapstain ascomycete (Ophiostoma angusticollis) forming dark perithecia with long narrow necks releasing the ascospores when growing on eucalypt (E. globulus) wood; and b white-rot basidiomycete (Phlebia chrysocrea) forming yellow-colored effused basidioma on wood (Laurelia philipiana) surface

fungi seem unable to efficiently remove free sterols from hardwoods (Fig. 3b) and resin acids from softwoods (Fig. 2b,e) (Chen et al. 1994; Dorado et al. 2000a; Gutiérrez et al. 1999b; Josefsson et al. 2006; Leone and Breuil 1998; Martínez-Íñigo et al. 1999). In contrast, a significant decrease of free sterols (up to $60 \%$ ) has been reported by Su et al. (2004).

In addition to pitch reduction, albino strains of $O$. piliferum and related species exert a biocontrol effect, preventing sapstaining and other wood-rotting fungi from growing on logs and wood chips (Held et al. 2003). This is due to the ability of $O$. piliferum as an early wood colonizer, which is specially manifested when applied on freshly cut wood, and results in excluding not only late wood colonizers (such as white-rot fungi) but also other sapstaining species that are not able to start wood 
colonization due to the previous presence of the albino strain. When Cartapip is used as biocontrol agent it has the tradename Sylvanex ${ }^{\mathrm{TM}}$. In 2008, the current owners of the technology, Parrac Ltd., improved production and storage qualities of the product and are now announcing the relaunching of Cartapip 97/Sylvanex 97 worldwide. Generally, this technology can refer to any albino Ophiostoma strain that can be used for resin decrease, also resulting in maintenance of brightness levels in transportation and storage of wood prior to pulping (Farrell 2007).

\section{White-rot fungi}

White-rot fungi are the predominant degraders of lignin in nature. Some species preferentially degrade lignin to wood polysaccharides ("selective degraders"), whereas other species degrade all wood components simultaneously ("simultaneous degraders"). The ability of white-rot fungi to attack all major cell wall components, including lignin, cellulose and hemicelluloses is well characterized (Blanchette 1995; Martínez et al. 2005). In addition, some information regarding the degradation of non-structural components in the woody tissue such as wood extractives by white-rot fungi (preferentially, species producing a selective degradation pattern) has also been generated.

Some studies report the fungal degradation of lipophilic extractives in sapwood and heartwood from Scots pine by white-rot fungi compared with sapstain fungi (MartínezÍñigo et al. 1999). Triglycerides, fatty acids, sterol esters and waxes in pine sapwood were almost completely degraded by all the fungi assayed (Fig. 2). Moreover, sterols and resin acids were extensively degraded by the white-rot strains, but very poorly removed by the sapstain fungi. This work shows that the fungal degradation of heartwood extractives was not only limited by the degradative ability of the various tested fungi, but also by the inhibitory effect exerted by the extractive fraction. The white-rot fungus Funalia trogii was particularly inhibited on heartwood, whereas Bjerkandera sp. showed a higher tolerance to toxic extractives and was the most efficient fungus in degrading extractives in Scots pine heartwood and sapwood (Fig. 2c and f). Resin acids were reported to cause inhibition of other wood-inhabiting fungi (Eberhardt et al. 1994).

In another study, several white-rot fungi were tested for removal and detoxification of extractives from Scots pine sapwood and the timecourse of extractives degradation by two selected species namely Bjerkandera sp. and Trametes versicolor was monitored (Dorado et al. 2000b, 2001). These authors showed a fungal removal up to $90 \%$ of most lipophilic extractives that was accompanied by a seven to 17-fold reduction in toxicity in the Microtox bioassay. Further studies were performed by these authors with $T$. versicolor to evaluate the effect of the fungal treatment of spruce chips on a laboratory scale, in terms of pulp and paper quality, thermomechanical pulping (TMP) parameters, and effluent toxicity, to identify advantages and potential problems before a pilot-scale trial (van Beek et al. 2007).

On the other hand, several studies on lipophilic extractives removal from E. globulus wood showed that several white-rot fungi were able to remove up to $100 \%$ of all main lipophilic extractives present in this wood. These studies started with a screening of a large number of fungal species (21 ascomycetes, 33 basidiomycetes and 19 conidial fungi) including strains isolated from eucalypt wood (Martínez et al. 1999). Different patterns of lipophilic extractives degradation were analyzed (Gutiérrez et al. 1999b) and several white-rot basidiomycetes, including Phlebia species (Fig. 4b), were selected for their ability to efficiently remove (up to $100 \%$ ) both free and esterified sterols (Fig. 3c) abundant in eucalypt wood (Fig. 3a) unlike several ascomycete-type fungi including Cartapip ${ }^{\mathrm{TM}}$ that although they decreased the sterol ester content they did not decrease the amount of free sterols (Fig. 3b). Further, the timecourse of the fungal removal of these compounds were followed to optimize the duration of the fungal treatment with selected fungal species, namely Phlebia radiata, Ceriporiopsis subvermispora, Bjerkandera adusta, and Pleurotus pulmonarius (Martínez-Íñigo et al. 2000). Kraft pulping and TCF bleaching of the eucalypt chips treated with these four basidiomycetes, followed by papermaking evaluation of the pulps obtained, confirmed their potential for pitch biocontrol in hardwood pulping (Gutiérrez et al. 2000). Resin removal by wood chip treatment with whiterot fungi often has additional benefits in biomechanical and biochemical pulping due to the preferential removal of lignin resulting in energy savings (Akhtar et al. 2000; Bajpai et al. 2001).

\section{Enzymatic pitch control}

Enzymes offer an environmentally benign and efficient alternative to chemical reagents in many industrial applications. An enzymatic method to control pitch using a hydrolytic enzyme (lipase) to treat the pulp was the first case in the world in which an enzyme was successfully applied in the papermaking process. More recently, the high potential of oxidative enzymes for the removal of lipophilic compounds has been shown as described below.

\section{Hydrolytic enzymes}

Lipases (triacylglycerol acylhydrolases, EC 3.1.1.3) form a group of well-known hydrolytic enzymes. Their enzymology 
and structure (Fig. 5a) is discussed in several review papers, many of which also provide overviews of the wide range of industrial applications of these enzymes (Bornscheuer et al. 2002; Hasan et al. 2006). Lipase commercialized by Novozymes (Bagsvaerd, Denmark) under the trade name Resinase $^{\circledR}$ A2X was successfully applied at mill scale for the enzymatic control of pitch in softwood mechanical pulping in Japan in the early 1990s (Fujita et al. 1991, 1992; Hata et al. 1996; Matsukura et al. 1990). This enzymatic pitch control technology was initially developed in the 1980s by Jujo Paper Co. (later Nippon Paper) in conjunction with the Japanese office of Novozymes, and is still used nowadays. In Europe, pilot-scale trials for pitch control in softwood sulfite pulp using Resinase ${ }^{\circledR}$ also provided good results (Fischer and Messner 1992a, b, 1993). In addition

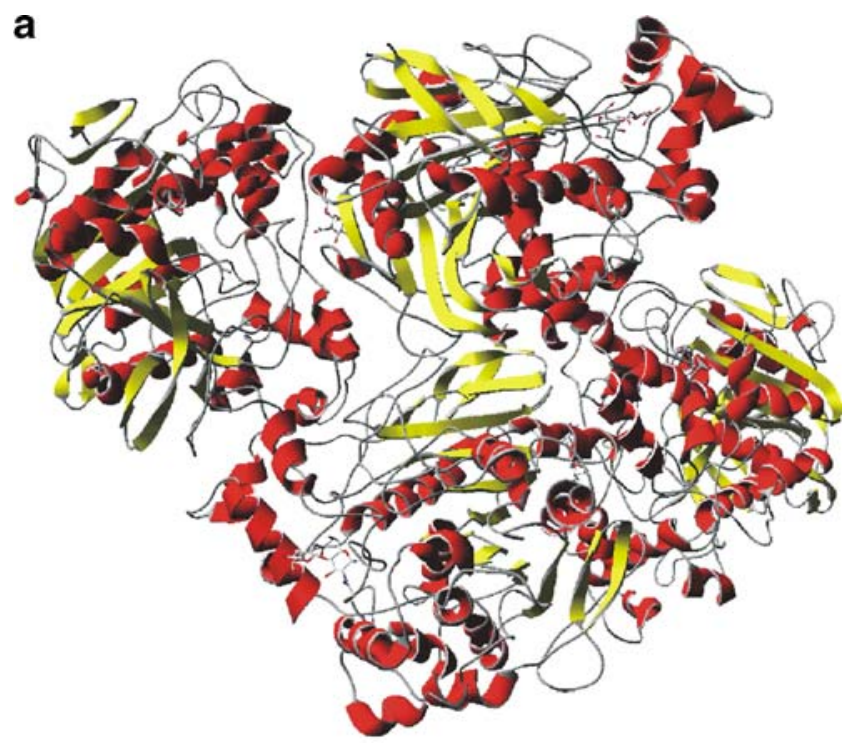

b

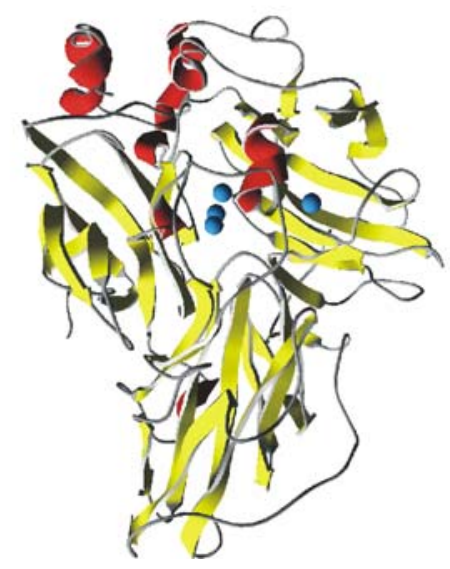

Fig. 5 Schematic representation of the molecular structures of enzymes of interest for pitch biocontrol: a Candida rugosa lipase-2 (PDB entry 1GZ7) forming a multienzymatic complex (Mancheno et al. 2003); and b Trametes versicolor laccase (PDB entry 1GYC) showing the catalytic coppers as blue spheres (Piontek et al. 2002). Regions with different secondary structure corresponding to helices (red) and $\beta$-sheets (yellow) are indicated to Resinase ${ }^{\circledR}$, other industrial lipases have been investigated for the enzymatic control of pitch (Gutiérrez et al. 2001b).

In December 1999, Nanping Paper Mill in China started the world fastest newsprint paper machine at this time, whose main pulp supply came from groundwood and TMP pulp using local Masson pine as raw material. Due to the very high content of lipophilic extractives of Masson pine, conventional pitch control programs were ineffective in preventing frequent pitch outbreaks on various parts of the paper machine during startup. In March 2000, the mill conducted a trial with a formulated pitch control treatment, which contained a variety of Novozymes enzymes including lipase products. The efforts focused not only on the operation of paper machine, but also on the pulp mills where the pitch had the highest concentration, and the pitch outbreaks were controlled successfully by the use of the enzyme-base treatment (Chen et al. 2001).

More recently, Novozymes developed by directed evolution a Resinase variant which is over $15^{\circ} \mathrm{C}$ more stable than the wild-type enzyme, in the frame of a EuropeanCommission-funded RTD-project (www.irnase.csic.es/ projects/pitch). The optimum temperature of this Resinase ${ }^{\circledR}$ HT ranges from 70 to $85^{\circ} \mathrm{C}$. Currently, Resinase ${ }^{\circledR} \mathrm{A} 2 \mathrm{X}$ and Resinase $^{\circledR}$ HT are used in mills from USA, Canada, China, Japan and other countries in the far east (that process wood species with very high resin content). Very recently, it has been shown that combining a novel ecological surfactant with a lipase it is possible to reduce a broad range of extractives in a softwood TMP pulp (Dubé et al. 2008).

Lipase treatments have been shown to reduce pulp triglycerides successfully, but in addition to triglycerides other compounds such as free and esterified sterols, resin acids, fatty alcohols, alkanes, etc. are also responsible of pitch problems as mentioned before. Sterol esterases (steryl-ester acylhydrolases, E.C. 3.1.1.13), which hydrolyze fatty acid esters of sterols, have also been suggested for pitch control (Calero-Rueda et al. 2004; Kontkanen et al. 2006b), because sterol esters are often at the origin of deposits. These enzymes are produced in mammalian tissues and by several fungi and bacteria (Panda and Gowrishankar 2005). In addition, some lipases have been reported to catalyze the hydrolysis of sterol esters (Kontkanen et al. 2004). However, it is worth mentioning that the hydrolysis of sterol esters would increase the amount of free sterols, which have been shown to increase the viscosity and deposition tendency of resin (Qin et al. 2003, 2004). Therefore, the hydrolysis of sterol esters would not be advantageous for the papermaking process (Kontkanen et al. 2006a; Qin et al. 2004). Little is known on the enzymes involved in enzymatic degradation of sterols and resin acids despite microbial degradation of these compounds has been reported as mentioned above (Gutiérrez et al. 1999b, 2001b; Hata et al. 1998; Liss et al. 1997; Marsheck et al. 1972; Martínez-Íñigo et al. 2000). 
Therefore, enzymes acting on a broader range of substrates are being investigated.

\section{Oxidative enzymes}

Oxidoreductases have been object of interest in the pulp and paper industry with the aim of developing environmentally sound technologies for pulp delignification and bleaching. Among them, laccases (EC 1.10.3.2) constitute a group of oxidative enzymes whose interest has grown significantly in recent years (Mayer and Staples 2002; Riva 2006; Rodríguez Couto and Tocca Herrera 2006; Widsten and Kandelbauer 2008). Laccases are metalloenzymes including four catalytic coppers in their molecular structure (Fig. 5b). Due to the redox potential of the copper cofactors, the direct action of laccases is in principle limited to phenolic structures that only represent a small percentage in lignin. Therefore, more attention was initially paid to peroxidases than to laccases in both lignin biodegradation studies, and in the development of biotechnological applications (Paice et al. 1995).

However, the interest on laccases as industrial biocatalysts strongly increased after discovering the effect of some synthetic compounds, including 2,2'-azinobis(3-ethylbenzothiazoline-6-sulphonic acic; ABTS; Bourbonnais and Paice 1990) and 1-hydroxybenzotriazole (HBT; Call 1994), which expanded the action of laccase to non-phenolic substrates increasing their potential in the degradation of lignin and, therefore, their potential for pulp bleaching (Bourbonnais and Paice 1996; Camarero et al. 2004; Ibarra et al. 2007; Poppius-Levlin et al. 1999; Sealey et al. 1999).

In addition to its action on phenolic compounds, some reactivity of laccase (from a Trametes species) on polyunsaturated fatty acids $(20 \%$ decrease after $4 \mathrm{~h})$ and conjugated resin acids ( $29 \%$ decrease) was first reported by Karlsson et al. (2001) and a similar action (20-35\% reduction after $3 \mathrm{~h}$ ) of laccase on trilinolein was reported (Zhang et al. 2002). In the reaction of trilinolein, the dominant oxidation products detected were monohydroperoxides, bishydroperoxides and epoxides. Likewise, a decrease over $30 \%$ of lipophilic extractives present in softwood pulp from TMP pulping and process waters was also reported (Buchert et al. 2002; Dubé et al. 2008; Zhang et al. 2000, 2005).

Very recently, it was reported for the first time the high efficiency of the laccase-mediator system for the removal of lipophilic extractives present in pulps from different origins regardless the pulping process, the raw material or the chemical nature of the compound to be degraded (Gutiérrez et al. 2006b) and a patent application was filed (Gutiérrez et al. 2006c). In these studies, the laccase from the basidiomycete Pycnoporus cinnabarinus in the presence of the mediator HBT was very efficient in removing free and conjugated sterols (95-100\% decrease) from eucalypt kraft pulp; triglycerides, resin acids and sterols (65-100\% decrease) from spruce TMP pulp; and fatty alcohols, alkanes and sterols (40-100\% decrease) from flax soda pulp (Fig. 6). The removal of lipids by laccase-HBT resulted in the formation of several oxidized derivatives that were absent or presented low abundances in the initial pulps. In spite of this, the total lipid content in pulps decreased significantly, and the most problematic compounds were completely removed. In another work, this enzymatic treatment was applied as an additional stage of an industrial-type TCF sequence for bleaching eucalypt kraft pulp (Gutiérrez et al. 2006a) showing the complete removal of free and conjugated sitosterol. Pulp brightness was also improved due to the simultaneous removal of lignin by the laccase-mediator treatment.

Further investigations on the chemistry of the reactions of the laccase-mediator system with model lipids representative for the main lipophilic extractives present in hardwood, softwood and non-wood paper pulps (including alkanes, fatty alcohols, fatty acids, resin acids, free sterols, sterol esters and triglycerides) were carried out, and the reaction products were identified and quantified during the treatment, to better understand the degradation patterns observed in pulps (Molina et al. 2008). These studies evidenced that a $60-100 \%$ decrease of the initial amount of unsaturated compounds such as abietic acid, trilinolein, linoleic and oleic acids, sitosterol, cholesteryl palmitate, oleate and linoleate, was found at the end of 2-h laccaseHBT treatment. Likewise, a decrease of $20-40 \%$ of these unsaturated lipids was observed after treatment with laccase alone except in the cases of abietic acid that decreased $95 \%$, and cholesteryl palmitate and sitosterol that were not affected.

The above-study confirmed that laccase alone decreased the concentration of some unsaturated lipids (Karlsson et al. 2001; Zhang et al. 2002). However, the most rapid and extensive lipid modification was obtained with the laccasemediator system (Molina et al. 2008). Model unsaturated lipids were largely oxidized and the dominant products detected were epoxy and hydroxy-fatty acids from fatty acids, and free and esterified 7-ketosterols and steroid ketones from sterols and sterol esters. In the case of sterol linoleate, breakdown of the fatty acid chain is produced releasing the so-called core aldehydes. The enzymatic reaction on sterol esters largely depended on the nature of the fatty-acyl moiety, i.e., oxidation of saturated fatty acid esters started at the sterol moiety, whereas the initial attack of unsaturated fatty acid esters was produced on the fatty acid double bonds. In contrast, saturated lipids were not modified, although some of them decreased when the laccase-mediator reactions were carried out in the presence of unsaturated lipids suggesting participation of lipid peroxidation radicals. 
a

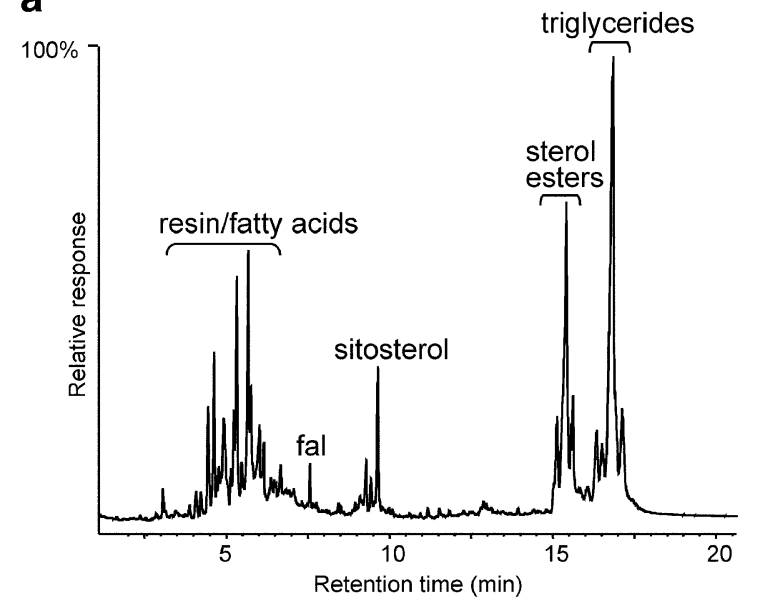

b
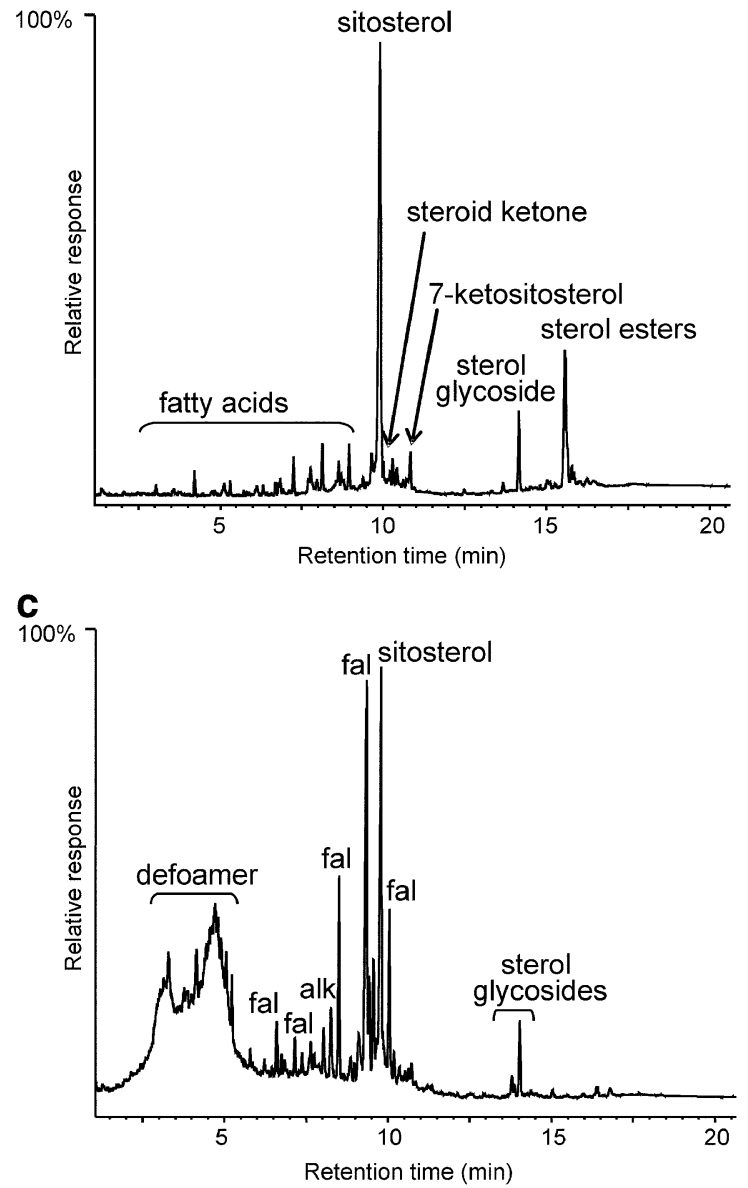

Fig. 6 Gas-chromatography analysis of lipophilic compounds in spruce TMP pulp (a and d), eucalypt kraft pulp (b and e), and flax soda/AQ pulp (c and f) before (a-c) and after (d-f) laccase-HBT

Since some issues concerning the use of HBT and related synthetic mediators (such as the high cost and possible toxicity) difficult its industrial application, the search for natural compounds that could act as laccase mediators has been objective of scientists. The existence of some fungal

\section{d}

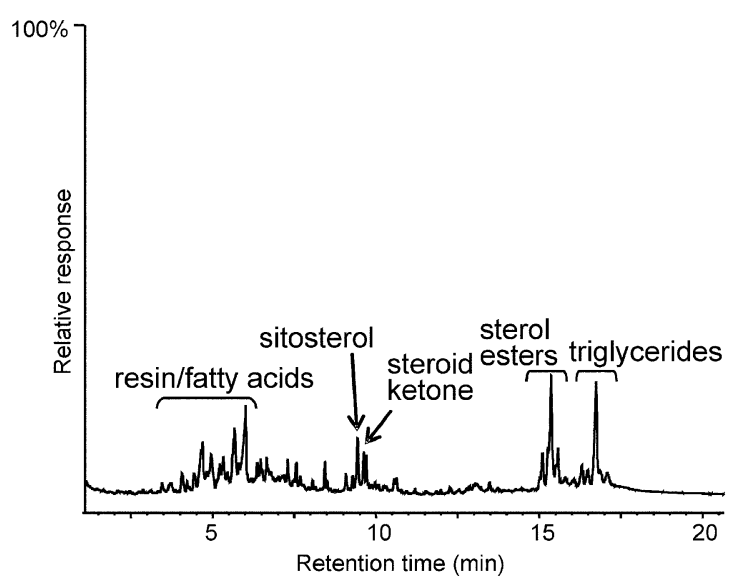

e

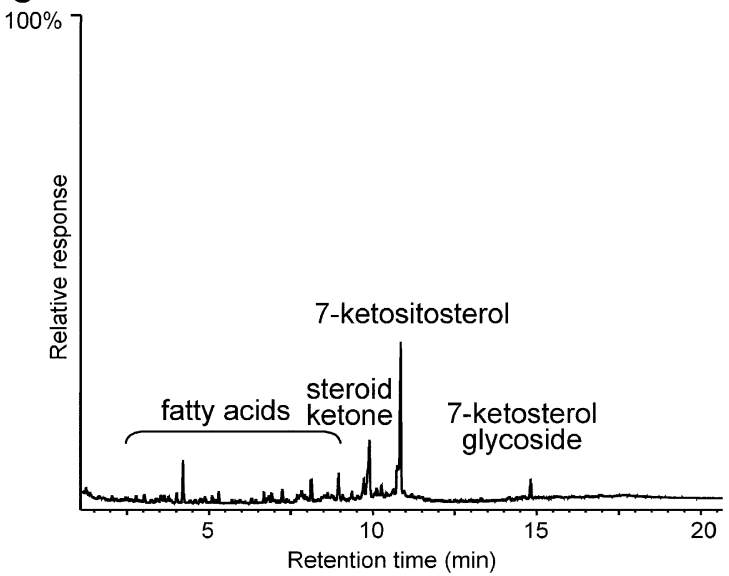

f

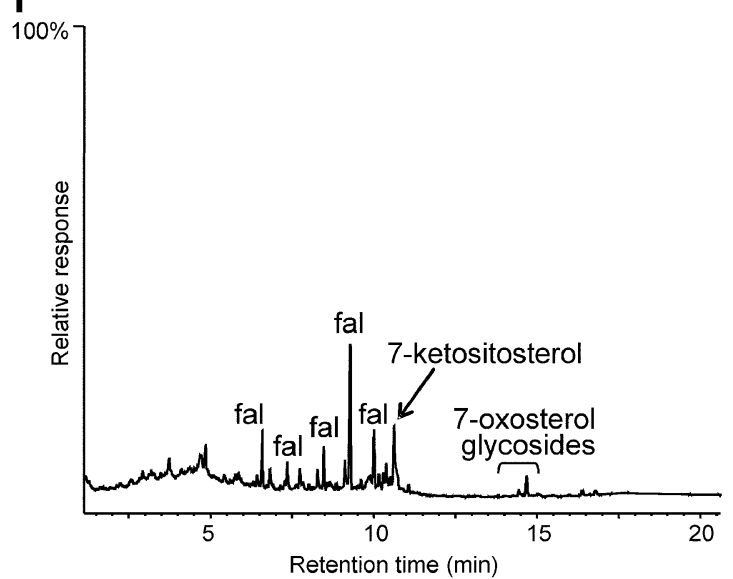

treatment. Abbreviations: fal fatty alcohols, and alk alkanes. Adapted from Gutiérrez et al. (2006a)

mediators has been suggested (Eggert et al. 1996; Gutiérrez et al. 1994). In this respect, it has been reported for the first time that cost-effective phenolic compounds related to lignin can act as laccase mediators for the removal of lipophilic compounds from paper pulp in the frame of a 
TCF sequence (Gutiérrez et al. 2007). These natural mediators represent an alternative to synthetic mediators, such as HBT (Camarero et al. 2005). In this study by Gutiérrez et al. (2007), unbleached eucalypt kraft pulp was treated with a fungal laccase in the presence of syringaldehyde, acetosyringone, and $p$-coumaric acid as mediators (Fig. 7). The enzymatic treatment using syringaldehyde (11) as mediator caused the highest removal (over 90\%) of free and conjugated sitosterol, similar to that attained with HBT, followed by acetosyringone (12; over $60 \%$ removal), whereas $p$-coumaric acid (13) was barely effective. Moreover, recalcitrant oxidized steroids surviving laccase-HBT treatment could be removed when using these natural mediators. Pulp brightness was also improved (from 57\% to $66 \%$ ISO brightness) by the laccase treatment in the presence of the above phenols followed by the peroxide stage due to the simultaneous removal of lignin. The use of natural compounds as laccase mediators makes these enzymatic treatments more feasible to be applied in the pulp and paper industry. However, more knowledge is needed before this enzymatic treatment for (simultaneous) removal of pulp pitch and lignin can be considered as a serious proposition to be implemented in the pulp and paper industry.

Finally, the use of lipoxygenases (EC 1.13.11.12), a class of non-heme iron-containing dioxygenases that catalyze the oxygenation of unsaturated fatty acids and their esters, has been recently suggested for pitch control in softwood TMP pulp (Zhang et al. 2007). Lipoxygenases are ubiquitous in plant, mammalian, and fungal species. Despite extensive studies on their biochemical and molecular properties (Brash 1999; Saam et al. 2007), this group of enzymes has not been used yet in industrial processing. The specific activity of lipoxygenases to degrade linoleic acid leads to a potential application in papermaking processes to degrade lipophilic extractives. In the work by Zhang et al. (2007), the lipophilic extractives content of TMP pulp samples was reduced by more than $25 \%$ after a 2 -h treatment with soybean lipoxygenase. In this work, the activity of lipoxygenase towards wood extractives was determined by using a mixture extracted from TMP. Lipoxygenase exhibited a significant activity towards these wood extractives. However, it was found that some of the extractives

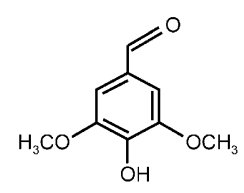

11

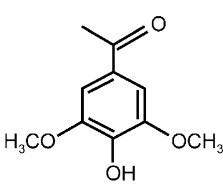

12

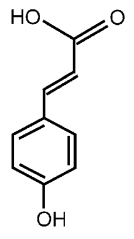

13
Fig. 7 Three natural phenols used as laccase mediators for pitch removal: 11, syringaldehyde; 12, acetosyringone, and 13, $p$-coumaric acid (Gutiérrez et al. 2007) (such as resin acids) and lignin products may have inhibitory effects on lipoxygenase-catalyzed reactions with linoleic acid. Earlier work in a patent by Novozymes had suggested the possibility of using lipoxygenases to degrade a model wood "pitch" mixture containing linoleic acid, abietic acid, oleic acid, and olive oil (Borch et al. 2003). Additional studies on lipoxygenases for pitch biocontrol are currently in course (Nguyen et al. 2007).

\section{Concluding remarks and future trends}

Lipophilic extractives responsible for pitch problems include fatty acids, fatty alcohols, resin acids, hydrocarbons, steroids, triterpenoids and triglycerides. Therefore, biotechnological technologies capable of modifying these compounds would be potential tools for reducing pitch problems during pulp and paper manufacture. In the 1990s, two biotechnological applications for pitch control were successfully developed, and applied at full mill industrial scale in various parts of the world. The fungal method for pitch control, using a colorless isolate of $O$. piliferum, was the first successful case of using a live organism as a solution to pitch problems, particularly in softwood mechanical pulping. Likewise, the enzymatic method for pitch control using lipase was the first successful example of the use of an enzyme as a solution to pitch problems in the papermaking process. In both cases, triglycerides were the main responsible of pitch problems. Since then, several works have been carried out to find a biotechnological solution to pitch problems caused by other lipophilic extractives such as free and esterified sterols, as well as resin acids.

Biotechnological processes based on the use of selective white-rot fungi could have some advantages compared to sapstain fungi. Some lipophilic extractives, such as triglycerides and fatty acids are easily degraded by different fungi, and even an effective hydrolysis of sterol esters can be achieved by several ascomycetous fungi including sapstain species. However, free sterols and triterpenols as well as resin acids are more recalcitrant towards microbial degradation, and better removal has been obtained with white-rot basidiomycetes. In addition to the advantages directly resulting from the removal of wood extractives, white-rot fungi could accomplish other significant benefits. Wood chip pretreatment with white-rot fungi capable of degrading lignin (and recalcitrant extractives) selectively, a process known as biopulping, enables substantial savings in energy required for obtaining mechanical pulps. Unlike white-rot fungi, ascomycetes are unable to attack lignin. Therefore, such fungal treatments are not expected to reduce the energy requirements. Another limitation of sapstain ascomycetes is their poor ability to colonize the 
heartwood of most softwood species. Taking into account that the total amount of extractives in heartwood is generally much higher than in sapwood, the low susceptibility of heartwood to biological colonization by sapstain fungi limits the effectiveness of wood depitching. The applicability of white-rot fungi in pulpwood depitching would greatly depend on their effects on pulp yield and properties. Fungal attack of cellulose in pulp fibers is highly undesirable as it causes reduction in yield and pulp strength properties. Therefore, these biodepitching/biopulping treatments need to be applied under controlled conditions (including treatment duration) to attain a maximal removal of lipids and lignin with a minimal deterioration of fibers and hydrolysis of cellulose.

The use of enzymes to remove extractives from pulp has advantages, compared to the use of fungal inocula to remove extractives from the wood before pulping, such as the shorter treatment times and the higher specificity in the removal of wood components. Commercial lipases are successful in the hydrolysis of triglycerides in softwood mechanical pulps, being currently used in different types of mills. Recently, some promising results have been reported by the use of oxidative enzymes, particularly laccases in the presence of redox mediators that are effective on several lipophilic extractives such as fatty acids, resin acids, free and conjugated sterols and triglycerides. Laccases are characteristic of white-rot fungi and, as in the case of wood treatment with these lignin-degrading basidiomycetes, a double benefit can be obtained from their application on pulps in the presence of redox mediators. These compounds enable laccase removal of residual lignin, as well as extensive degradation of pulp extractives including the most recalcitrant compounds, such as sterols and resin acids.

Biotechnology, for both pitch control and lignin removal, was introduced in the paper pulp mill more than 15 years ago, with the application of lipases and xylanases on pulp, and sapstaining fungi on wood. From this date, the potential of selective lignin degraders from the group of white-rot fungi (such as C. subvermispora) has been demonstrated for energy-saving and improving pulp properties in biomechanical pulping processes, amongst others. Simultaneously, a variety of other hydrolytic enzymes have been investigated for application in pulp and paper manufacturing including, among others, pectinases, esterases and cellulases (for improving debarking of logs, deinking of waste paper, and dewatering at the paper machine, respectively) and they have attained the mill in some cases. Moreover, the studies with oxidative enzymes suggested a bright future of some of them in the pulp and paper sector. In particular, the above-mentioned laccase-mediator systems would permit effective removal of pulp lipids (decreasing pitch problems) and improved pulp delignification (resulting in high brightness degree and stability) using the same enzymatic preparation. The cost and environmental concerns associated to the use of synthetic mediators (such as $\mathrm{NOH}$ type compounds) could be overcome by using natural mediators, such as lignin-related phenols obtained from easily available sources (such as pulping liquors) at the same time than the cost of the enzymes would be decreased by the use of genetic engineering techniques (as in the case of the other industrial enzymes used in the sector).

Acknowledgments This work was supported by the Spanish projects AGL2008-00709, BIO2005-03569 and BIO2008-01533, and the BIORENEW project of the European Union (contract NMP2-CT2006-026456).

\section{References}

Akhtar M, Scott GM, Swaney RE, Shipley DF (2000) Biomechanical pulping: a mill-scale evaluation. Resour Conserv Recycl 28:241252

Allen LH (2000a) Pitch control in paper mills. In: Back EL, Allen LH (eds) Pitch control wood resin and deresination. TAPPI, Atlanta, pp 307-328

Allen LH (2000b) Pitch control in pulp mills. In: Back EL, Allen LH (eds) Pitch control wood resin and deresination. TAPPI, Atlanta, pp 265-288

Back EL (2000) The location and morphology of resin components in the wood. In: Back EL, Allen LH (eds) Pitch control wood resin and deresination. Tappi, Atlanta, pp 1-35

Back EL, Allen LH (2000) Pitch control wood resin and deresination. TAPPI, Atlanta

Bajpai P, Bajpai PK, Akhtar M, Jauhari MB (2001) Biokraft pulping of eucalyptus with selected lignin-degrading fungi. J Pulp Paper Sci 27:235-239

Bergelin E, Holmbom B (2003) Deresination of birch kraft pulp in bleaching. J Pulp Paper Sci 29:29-34

Bergelin E, Moller R, Holmbom B (2005) Analysis of pitch and deposit samples in kraft pulp production. Pap Puu-Pap Tim 87:399-403

Blanchette RA (1995) Degradation of the lignocellulose complex in wood. Can J Bot 73:S999-S1010

Borch K, Franks N, Lund H, Xu H, Luo J (2003) Oxidizing enzymes in the manufacturing of paper materials. Patent (USA) US 2003/ 0124710 A1

Bornscheuer U, Bessler C, Srinivas R, Hari KS (2002) Optimizing lipases and related enzymes for efficient application. Trends Biotechnol 20:433-437

Bourbonnais R, Paice MG (1990) Oxidation of non-phenolic substrates. An expanded role for laccase in lignin biodegradation. FEBS Lett 267:99-102

Bourbonnais R, Paice MG (1996) Enzymatic delignification of kraft pulp using laccase and a mediator. Tappi J 79:199-204

Brash AR (1999) Lipoxygenases: occurrence, functions, catalysis, and acquisition of substrate. J Biol Chem 274:23679-23682

Brush T, Farrell RL, Ho C (1994) Biodegradation of wood extractives from Southern and Yellow pine by Ophiostoma piliferum. Tappi J $77: 155-159$

Buchert J, Mustranta A, Tamminen T, Spetz P, Holmbom B (2002) Modification of spruce lignans with Trametes hirsuta laccase. Holzforschung 56:579-584 
Burnes TA, Blanchette RA, Farrell RL (2000) Bacterial biodegradation of extractives and patterns of bordered pit membrane attack in pine wood. Appl Environ Microbiol 66:5201-5205

Calero-Rueda O, Gutiérrez A, del Río JC, Prieto A, Plou FJ, Ballesteros A, Martínez AT, Martínez MJ (2004) Hydrolysis of sterol esters by an esterase from Ophiostoma piceae: application for pitch control in pulping of Eucalyptus globulus wood. Intern J Biotechnol 6:367-375

Call H-P (1994) Verfahren zur Veränderung, Abbau oder Bleichen von Lignin, ligninhaltigen Materialien oder ähnlichen Stoffen. Patent (International) WO 94/29510

Camarero S, García O, Vidal T, Colom J, del Río JC, Gutiérrez A, Gras JM, Monje R, Martínez MJ, Martínez AT (2004) Efficient bleaching of non-wood high-quality paper pulp using laccasemediator system. Enzyme Microb Technol 35:113-120

Camarero S, Ibarra D, Martínez MJ, Martínez AT (2005) Ligninderived compounds as efficient laccase mediators for decolorization of different types of recalcitrant dyes. Appl Environ Microbiol $71: 1775-1784$

Chen T, Wang Z, Gao Y, Breuil C, Hatton JV (1994) Wood extractives and pitch problems: analysis and partial removal by biological treatment. Appita 47:463-466

Chen T, Wang Z, Zhou Y, Breuil C, Aschim OK, Yee E, Nadeau L (1995) Using solid-phase extraction to assess why aspen causes more pitch problems than softwoods in kraft pulping. Tappi J 78:143-149

Chen S, Lin Y, Zhang Y, Wang XH, Yang JL (2001) Enzymatic pitch control at Nanping paper mill. Tappi J 84:44-47

del Río JC, Gutiérrez A (2006) Chemical composition of abaca (Musa textilis) leaf fibers used for manufacturing of high quality paper Pulps. J Agric Food Chem 54:4600-4610

del Río JC, Gutiérrez A, González-Vila FJ, Martín F, Romero J (1998) Characterization of organic deposits produced in the Kraft pulping of Eucalyptus globulus wood. J Chromatogr 823:457-465

del Río JC, Gutiérrez A, González-Vila FJ (1999) Analysis of impurities occurring in a totally-chlorine free-bleached Kraft pulp. J Chromatogr 830:227-232

del Río JC, Romero J, Gutiérrez A (2000) Analysis of pitch deposits produced in Kraft pulp mills using a totally chlorine free bleaching sequence. J Chromatogr A 874:235-245

Dorado J, Claassen FW, Lenon G, van Beek TA, Wijnberg JBPA, Sierra-Alvarez R (2000a) Degradation and detoxification of softwood extractives by sapstain fungi. Bioresource Technol 71:13-20

Dorado J, Claassen FW, van Beek TA, Lenon G, Wijnberg JBPA, Sierra-Alvarez R (2000b) Elimination and detoxification of softwood extractives by white-rot fungi. J Biotechnol 80:231-240

Dorado J, van Beek TA, Claassen FW, Sierra-Alvarez R (2001) Degradation of lipophilic wood extractive constituents in Pinus sylvestris by the white-rot fungi Bjerkandera sp. and Trametes versicolor. Wood Sci Technol 35:117-125

Dubé E, Shareck F, Hurtubise Y, Beauregard M, Daneault C (2008) Enzyme-based approaches for pitch control in thermomechanical pulping of softwood and pitch removal in process water. J Chem Technol Biotechnol 83:1261-1266

Eberhardt TL, Han JS, Micales JA, Young RA (1994) Decay resistance in conifer seed cones - role of resin acids as inhibitors of decomposition by white-rot fungi. Holzforschung 48:278-284

Eggert C, Temp U, Dean JFD, Eriksson K-EL (1996) A fungal metabolite mediates degradation of non-phenolic lignin structures and synthetic lignin by laccase. FEBS Lett 391:144-148

Ekman R (2000) Resin during storage and its biological treatment. In: Back EL, Allen LH (eds) Pitch control wood resin and deresination. Tappi, Atlanta, pp 185-204

Ekman R, Holmbom B (2000) The chemistry of wood resin. In: Back EL, Allen LH (eds) Pitch control wood resin and deresination. TAPPI, Atlanta, pp 37-76
Farrell RL (2007) Cartapip/SylvanexTM: Ophiostoma fungal product for commercial pulp and paper and solid wood applications. Proc 10 Intern Congr Biotechnology in the Pulp and Paper Industry, Madison, 10-14 June 63-64

Farrell RL, Blanchette RA, Brush TS, Hadar Y, Iverson S, Krisa K, Wendler PA, Zimmerman W (1993) Cartapip ${ }^{\mathrm{TM}}$ : a biopulping product for control of pitch and resin acid problems in pulp mills. J Biotechnol 30:115-122

Fengel D, Wegener G (1984) Wood: Chemistry, ultrastructure reactions. De Gruyter, Berlin

Fischer K, Messner K (1992a) Adsorption of lipase on pulp fibers during biological pitch control in paper industry. Enzyme Microb Technol 14:470-473

Fischer K, Messner K (1992b) Biological pitch reduction of sulfite pulp on pilot scale. In: Kuwahara M, Shimada M (eds) Biotechnology in the pulp and paper industry. UNI, Kyoto, pp 169-174

Fischer K, Puchinger L, Schloffer K (1993) Enzymatic pitch control of sulfite pulp on pilot scale. J Biotechnol 27:341-348

Freire CSR, Silvestre AJD, Neto CP (2002) Identification of new hydroxy fatty acids and ferulic acid esters in the wood of Eucalyptus globulus. Holzforschung 56:143-149

Freire CSR, Silvestre AJD, Neto CP (2005) Lipophilic extractives in Eucalyptus globulus kraft pulps. Behavior during ECF bleaching. J Wood Chem Technol 25:67-80

Freire CSR, Silvestre AJD, Neto CP, Evtuguin DV (2006) Effect of oxygen, ozone and hydrogen peroxide bleaching stages on the contents and composition of extractives of Eucalyptus globulus kraft pulps. Bioresource Technol 97:420-428

Fujita Y, Awaji H, Matsukura M, Hata K (1991) Enzymic pitch control in papermaking process. Kami Pa Gikyoshi 45:905-921

Fujita Y, Awaji H, Taneda H, Matsukura M, Hata K, Shimoto H, Sharyo M, Sakaguchi H, Gibson K (1992) Recent advances in enzymic pitch control. Tappi J 75(4):117-122

González-Vila FJ, Gutiérrez A, Martín F, Verdejo T (1997) Application of analytical pyrolysis to the characterization of Eucalyptus extractives and pitch deposits from a pulp mill. J Anal Appl Pyrolysis 40-41:501-510

Gutiérrez A, del Río JC (2001) Gas chromatography-mass spectrometry demonstration of steryl glycosides in eucalypt wood, kraft pulp and process liquids. Rapid Commun Mass Spectrom 15:2515-2520

Gutiérrez A, del Río JC (2003a) Lipids from flax fibers and their fate in alkaline pulping. J Agric Food Chem 51:4965-4971

Gutiérrez A, del Río JC (2003b) Lipids from flax fibers and their fate in alkaline pulping (Vol 51, pg 4965, 2003). J Agric Food Chem 51:6911-6914

Gutiérrez A, del Río JC (2005) Chemical characterization of pitch deposits produced in the manufacturing of high-quality paper pulps from hemp fibers. Bioresource Technol 96:1445-1450

Gutiérrez A, Caramelo L, Prieto A, Martínez MJ, Martínez AT (1994) Anisaldehyde production and aryl-alcohol oxidase and dehydrogenase activities in ligninolytic fungi from the genus Pleurotus. Appl Environ Microbiol 60:1783-1788

Gutiérrez A, del Río JC, González-Vila FJ, Romero J (1998) Variation in the composition of wood extractives from Eucalyptus globulus during seasoning. J Wood Chem Technol 18:439-446

Gutiérrez A, del Río JC, González-Vila FJ, Martín F (1999a) Chemical composition of lipophilic extractives from Eucalyptus globulus Labill. wood. Holzforschung 53:481-486

Gutiérrez A, del Río JC, Martínez MJ, Martínez AT (1999b) Fungal degradation of lipophilic extractives in Eucalyptus globulus wood. Appl Environ Microbiol 65:1367-1371

Gutiérrez A, Martínez MJ, del Río JC, Romero J, Canaval J, Lenon G, Martínez AT (2000) Fungal pretreatment of Eucalyptus wood can strongly decrease the amount of lipophilic extractives 
during chlorine-free kraft pulping. Environ Sci Technol 34:37053709

Gutiérrez A, del Río JC, Martínez MJ, Martínez AT (2001a) The biotechnological control of pitch in paper pulp manufacturing. Trends Biotechnol 19:340-348

Gutiérrez A, Romero J, del Río JC (2001b) Lipophilic extractives from Eucalyptus globulus pulp during kraft cooking followed by TCF and ECF bleaching. Holzforschung 55:260-264

Gutiérrez A, Romero J, del Río JC (2001c) Lipophilic extractives in process waters during manufacturing of totally chlorine free kraft pulp from eucalypt wood. Chemosphere 44:1237-1242

Gutiérrez A, Rodríguez IM, del Río JC (2004) Chemical characterization of lignin and lipid fractions in kenaf bast fibers used for manufacturing high-quality papers. J Agric Food Chem 52:47644773

Gutiérrez A, del Río JC, Ibarra D, Rencoret J, Romero J, Speranza M, Camarero S, Martínez MJ, Martínez AT (2006a) Enzymatic removal of free and conjugated sterols forming pitch deposits in environmentally sound bleaching of eucalypt paper pulp. Environ Sci Technol 40:3416-3422

Gutiérrez A, del Río JC, Rencoret J, Ibarra D, Martínez AT (2006b) Main lipophilic extractives in different paper pulp types can be removed using the laccase-mediator system. Appl Microbiol Biotechnol 72:845-851

Gutiérrez A, del Río JC, Rencoret J, Ibarra D, Speranza AM, Camarero S, Martínez MJ, Martínez AT (2006c) Sistema enzimamediador para el control de los depósitos de pitch en la fabricación de pasta y papel. Patent (International) PCT/ES06/070091

Gutiérrez A, Rodríguez IM, del Río JC (2006d) Chemical characterization of lignin and lipid fractions in industrial hemp bast fibers used for manufacturing high-quality paper pulps. J Agric Food Chem 54:2138-2144

Gutiérrez A, Rencoret J, Ibarra D, Molina S, Camarero S, Romero J, del Río JC, Martínez AT (2007) Removal of lipophilic extractives from paper pulp by laccase and lignin-derived phenols as natural mediators. Environ Sci Technol 41:4124-4129

Gutiérrez A, Rodríguez IM, del Río JC (2008) Chemical composition of lipophilic extractives from sisal (Agave sisalana) fibers. Ind Crops Prod 28:81-87

Hasan F, Shah AA, Hameed A (2006) Industrial applications of microbial lipases. Enzyme Microb Technol 39:235-251

Hata K, Matsukura M, Taneda H, Fujita Y (1996) Mill-scale application of enzymatic pitch control during paper production. In: Viikari L, Jeffries TW (eds) Enzymes for pulp and paper processing. ACS, Washington, pp 280-296

Hata K, Matsukura M, Fujita Y, Toyota K, Taneda H (1998) Biodegradation of resin acids in pulp and paper industry: application of microorganisms and their enzymes. ACS Sym Ser 687:27-40

Held BW, Thwaites JM, Farrell RL, Blanchette RA (2003) Albino strains of Ophiostoma species for biological control of sapstaining fungi. Holzforschung 57:237-242

Ibarra D, Chávez MI, Rencoret J, del Río JC, Gutiérrez A, Romero J, Camarero S, Martínez MJ, Jimenez-Barbero J, Martínez AT (2007) Structural modification of eucalypt pulp lignin in a totally chlorine free bleaching sequence including a laccase-mediator stage. Holzforschung 61:634-646

Jansson MB, Wormald P, Dahlman O (1995) Reactions of wood extractives during ECF and TCF bleaching of kraft pulp. Pulp Paper Can 96:T134-T137

Josefsson P, Nilsson F, Sundstrom L, Norberg C, Lie E, Jansson MB, Henriksson G (2006) Controlled seasoning of Scots pine chips using an albino strain of Ophiostoma. Industrial \& Engineering Chemistry Research 45:2374-2380

Kallioinen A, Vaari A, Ratto M, Konn J, Siikaaho M, Viikari L (2003) Effects of bacterial treatments on wood extractives. J Biotechnol 103:67-76
Karlsson S, Holmbom B, Spetz P, Mustranta A, Buchert J (2001) Reactivity of Trametes laccases with fatty and resin acids. Appl Microbiol Biotechnol 55:317-320

Kontkanen H, Tenkanen M, Fagerstrom R, Reinikainen T (2004) Characterisation of steryl esterase activities in commercial lipase preparations. J Biotechnol 108:51-59

Kontkanen H, Saloheimo M, Pere J, Miettinen-Oinonen A, Reinikainen T (2006a) Characterization of Melanocarpus albomyces steryl esterase produced in Trichoderma reesei and modification of fibre products with the enzyme. Appl Microbiol Biotechnol 72:696-704

Kontkanen H, Tenkanen M, Reinikainen T (2006b) Purification and characterisation of a novel steryl esterase from Melanocarpus albomyces. Enzyme Microb Technol 39:265-273

Leach JM, Thakore AN (1976) Toxic constituents in mechanical pulping effluents. Tappi 59:129-132

Leone R, Breuil C (1998) Filamentous fungi can degrade aspen steryl esters and waxes. Int Biodeterior Biodegrad 41:133-137

Liss SN, Bicho PA, Saddler JN (1997) Microbiology and biodegradation of resin acids in pulp mill effluents: a minireview. Can J Microbiol 43:599-611

Mancheno JM, Pernas MA, Martinez MJ, Ochoa B, Rua ML, Hermoso JA (2003) Structural insights into the lipase/esterase behavior in the Candida rugosa lipases family: crystal structure of the lipase 2 isoenzyme at $1.97 \mathrm{~A}$ resolution. J Mol Biol 332:1059-1069

Marsheck WJ, Kraychy S, Muir RD (1972) Microbial degradation of sterols. Appl Microbiol 23:72-77

Martínez MJ, Barrasa JM, Gutiérrez A, del Río JC, Martínez AT (1999) Fungal screening for biological removal of extractives from Eucalyptus globulus Labill. wood. Can J Bot 77:1513-1522

Martínez AT, Speranza M, Ruiz-Dueñas FJ, Ferreira P, Camarero S, Guillén F, Martínez MJ, Gutiérrez A, del Río JC (2005) Biodegradation of lignocellulosics: microbiological, chemical and enzymatic aspects of fungal attack to lignin. Intern Microbiol 8:195-204

Martínez-Iñigo MJ, Immerzeel P, Gutiérrez A, del Río JC, SierraAlvarez R (1999) Biodegradability of extractives in sapwood and heartwood from Scots pine by sapstain and white-rot fungi. Holzforschung 53:247-252

Martínez-Íñigo MJ, Gutiérrez A, del Río JC, Martínez MJ, Martínez AT (2000) Time course of fungal removal of lipophilic extractives from Eucalyptus globulus Labill. wood. J Biotechnol $84: 119-126$

Matsukura M, Fujita Y, Sakaguchi H (1990) On the use of Resinase ${ }^{\mathrm{TM}}$ A for pitch control. Novo A-6122:1-7

Mayer AM, Staples RC (2002) Laccase: new functions for an old enzyme. Phytochemistry 60:551-565

Molina S, Rencoret J, del Río JC, Lomascolo A, Record E, Martínez AT, Gutiérrez A (2008) Oxidative degradation of model lipids representative for main paper pulp lipophilic extractives by the laccase-mediator system. Appl Microbiol Biotechnol 80:211-222

Morrison WHI, Akin DE (2001) Chemical composition of components comprising bast tissue in flax. J Agric Food Chem 49:2333-2338

Nguyen D, Zhang X, Paice MG, Tsang A, Renaud S (2007) Microplate enzyme assay for screening lipoxygenases to degrade wood extractives. Biocatal Biotransform 25:202-210

Otero D, Sundberg K, Blanco A, Negro C, Holmbom B (2000) Effect of wood polysaccharides on the depositability of wood pitch. Nordic Pulp Paper Res J 15:607-613

Paice MG, Bourbonnais R, Reid ID, Archibald FS, Jurasek L (1995) Oxidative bleaching enzymes: a review. J Pulp Paper Sci 21:J280 J284

Panda T, Gowrishankar BS (2005) Production and applications of esterases. Appl Microbiol Biotechnol 67:160-169 
Piontek K, Antorini M, Choinowski T (2002) Crystal structure of a laccase from the fungus Trametes versicolor at 1.90- $\AA$ resolution containing a full complement of coppers. J Biol Chem 277:37663-37669

Poppius-Levlin K, Wang W, Tamminen T, Hortling B, Viikari L, Niku-Paavola M-L (1999) Effects of laccase/HBT treatment on pulp and lignin structures. J Pulp Paper Sci 25:90-94

Qin M, Hannuksela T, Holmbom B (2003) Physico-chemical characterization of TMP resin and related model mixtures. Colloids Surfaces A 221:243-254

Qin M, Hannuksela T, Holmbom B (2004) Deposition tendency of TMP resin and related model mixtures. J Pulp Paper Sci 30:279283

Rencoret J, Gutiérrez A, del Río JC (2007) Lipid and lignin composition of woods from different eucalypt species. Holzforschung 61:165174

Riva S (2006) Laccases: blue enzymes for green chemistry. Trends Biotechnol 24:219-226

Rocheleau MJ, Sitholé BB, Allen LH, Noel Y (1999) Fungal treatment of aspen for wood resin reduction: effect on aged aspen wood chips at room temperature and at $5^{\circ} \mathrm{C}$. Holzforschung $53: 16-20$

Rodríguez Couto S, Toca Herrera JL (2006) Industrial and biotechnologcial applications of laccases: a review. Biotechnol Adv 24:500-513

Saam J, Ivanov I, Walther M, Holzhutter HG, Kuhn H (2007) Molecular dioxygen enters the active site of 12/15-lipoxygenase via dynamic oxygen access channels. Proc Natl Acad Sci USA 104:13319-13324

Sealey J, Ragauskas AJ, Elder TJ (1999) Investigations into laccasemediator delignification of kraft pulps. Holzforschung 53:498502

Silvério FO, Barbosa LCA, Maltha CRA, Fidêncio PH, Cruz MP, Veloso DP, Milanez AF (2008) Effect of storage time on the composition and content of wood extractives in Eucalyptus cultivated in Brazil. Biores Technol 99:4878-4886

Silvestre AJD, Pereira CCL, Pascoal Neto C, Evtuguin DV, Duarte AC, Cavaleiro JAS, Furtado FP (1999) Chemical composition of pitch deposits from ECF Eucalyptus globulus bleached kraft pulp mill: Its relationship with wood extractives and additives in process streams. Appita J 52:375-382

Su Y, Wang EI, Farrell R, Ho C-I, Chang H-M (2004) Screening of fungi for removal of wood extractives. Proc 58th Appita Ann Conf Exhibit, Canberra, 19-24 April 27-34

van Beek TA, Kuster B, Claassen FW, Tienvieri T, Bertaud F, Lenon G, Petit-Conil M, Sierra-Alvarez R (2007) Fungal bio-treatment of spruce wood with Trametes versicolor for pitch control: Influence on extractive contents, pulping process parameters, paper quality and effluent toxicity. Bioresource Technol 98:302-311

Widsten P, Kandelbauer A (2008) Laccase application in the forest processing industries: a review. Enzyme Microb Technol 42:293307

Zhang X, Stebbing DW, Saddler JN, Beatson RP, Kruus K (2000) Enzyme treatments of the dissolved and colloidal substances present in mill white water and the effects on the resulting paper properties. J Wood Chem Technol 20:321-335

Zhang X, Eigendorf G, Stebbing DW, Mansfield SD, Saddler JN (2002) Degradation of trilinolein by laccase enzymes. Arch Biochem Biophys 405:44-54

Zhang X, Renaud S, Paice M (2005) The potential of laccase to remove extractives present in pulp and white water from TMP newsprint mills. J Pulp Paper Sci 31:175-180

Zhang X, Nguyen D, Paice MG, Tsang A, Renaud S (2007) Degradation of wood extractives in thermo-mechanical pulp by soybean lipoxygenase. Enzyme Microb Technol 40:866-873

Zimmerman WC, Blanchette RA, Burnes TA, Farrell RL (1995) Melanin and perithecial development in Ophiostoma piliferum. Mycologia 87:857-863 